\title{
Polychaetes associated with the sciaphilic alga community in the northern Aegean Sea: spatial and temporal variability
}

Received: 20 October 2003 / Revised: 14 April 2004 / Accepted: 22 April 2004 / Published online: 4 June 2004 (C) Springer-Verlag and AWI 2004

\begin{abstract}
Polychaete biodiversity has received little attention despite its importance in biomonitoring. This study describes polychaete diversity, and its spatial and temporal variability in infralittoral, hard substrate assemblages. Seven stations were chosen in the central area of the northern Aegean Sea. At each station, one to three depth levels were set $(15,30$ and $40 \mathrm{~m})$. Five replicates were collected by scuba diving with a quadrat sampler $\left(400 \mathrm{~cm}^{2}\right.$ ) from each station and depth level during summer for the spatial analysis, and seasonally for the study of temporal changes. Common biocoenotic methods were employed (estimation of numerical abundance, mean dominance, frequency, Margalef's richness, Shannon-Weaver index and Pielou's evenness). A total of 5,494 individuals, belonging to 79 species, were counted and classified. Diversity indices were always high. Clustering and multidimensional scaling techniques indicated a high heterogeneity of the stations, although these were all characterized by the sciaphilic alga community. A clear seasonal pattern was not detectable. Summer and autumn samples discriminate, while winter and spring form an even group. The abundance/biomass comparison indicated a dominance of k-strategy patterns, characteristic of stable communities.
\end{abstract}

Keywords Polychaeta $\cdot$ Infralittoral $\cdot$ Aegean Sea $\cdot$ Hard substrate $\cdot$ Biodiversity

Communicated by H.-D. Franke

C. Antoniadou · C. Chintiroglou (

School of Biology, Department of Zoology,

Aristotle University,

P.O. Box 134, 54006 Thessaloniki, Greece

e-mail: chintigl@bio.auth.gr

A. Nicolaidou

Zoological Laboratory,

University of Athens,

Panepistimiopolis, 15784 Athens, Greece

\section{Introduction}

There is a growing interest in biodiversity, defined as the collection of genomes, species and ecosystems occurring in a geographical region (CBDMS 1995). The most fundamental meaning of this term is expressed at species level by the concept of species richness (Bianchi and Morri 2000). Species richness does not simply refer to the number of species, but includes species variety, i.e. composition, which is an important indicator of diversity across spatial scales (Costello 1998). According to the Convention of Biological Diversity definition, biodiversity concerns variability within species (individual/population level), between species (community level), and at the ecosystem level (functional level). The value of biodiversity as an indicator of environment health, and for the functioning of ecosystems, is now largely recognized (Gaston and Spicer 1996; Bianchi and Morri 2000).

Polychaetes are among the most frequent and speciesrich taxa in marine benthic environments (Fauchald and Jumars 1979; Costello et al. 1996). Many authors have suggested a key role of polychaetes in biomonitoring studies (Reish 1978; Bellan 1980; Wenner 1988; Warwick 1986, 1993; Damianidis and Chintiroglou 2000). Before data from polychaete assemblages can be used to identify disturbances, as demanded by international directives and conventions, it is necessary to provide a database on the composition of natural assemblages (Pocklington and Wells 1992; Gaston and Spicer 1996; Ergen and Cinar 1997).

The distribution of polychaetes in hard-bottomed sites is commonly related to algal structure and zonation (Giangrande 1988; Somaschini 1988; Sardà 1991). However, the distribution of polychaetes depends on algal cover and epiphytes more than on the presence of particular macroalgal species (Abbiati et al. 1987; Sardà 1987; Giangrande 1988; Fraschetti et al. 2002). There is a large amount of literature on polychaetes in midlittoral and infralittoral zones of the western Mediterranean (Retiere and Richoux 1973; Cardell and Gili 1988; reviewed by Sardà 1991), yet much less information on the 
Fig. 1 Map of the study area

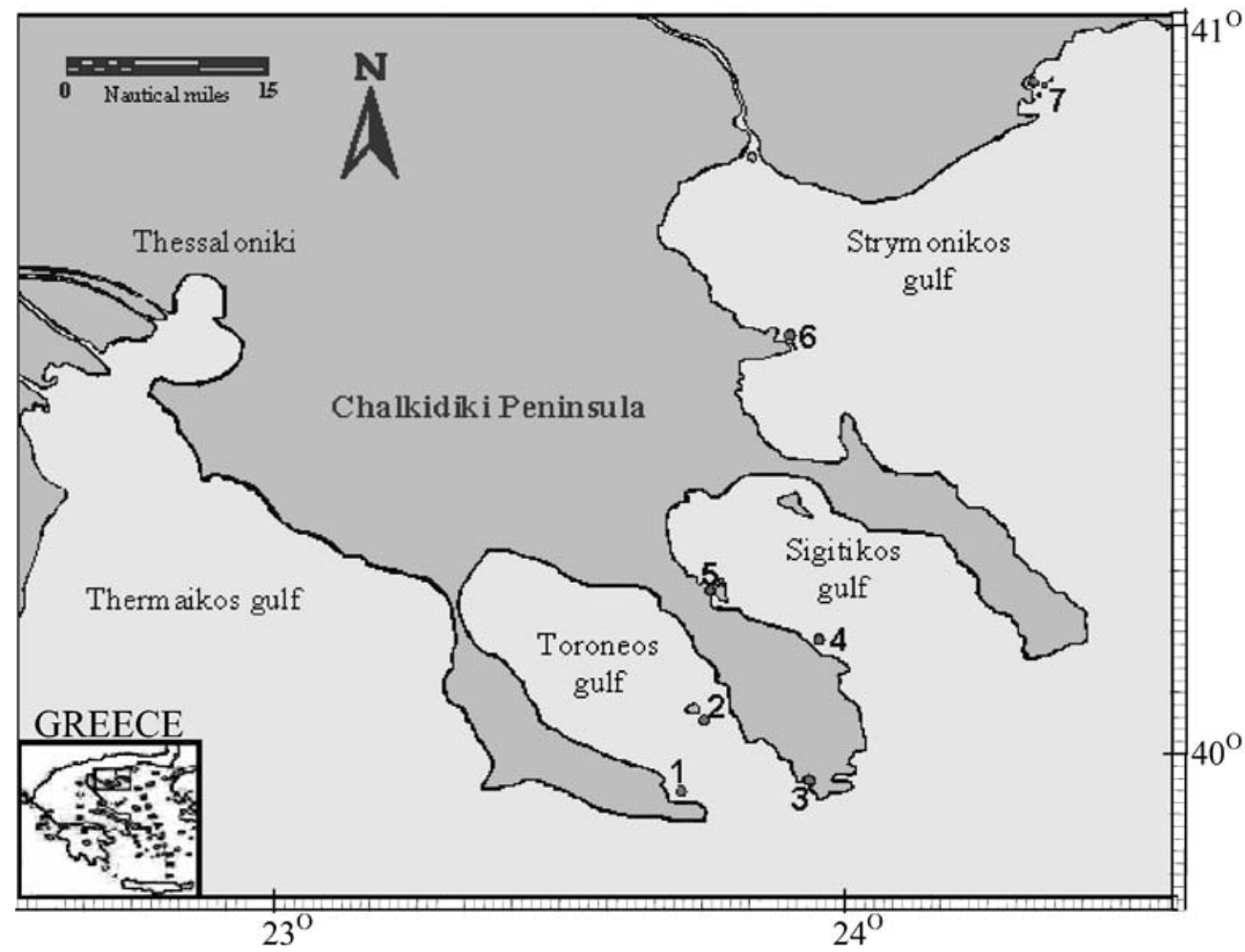

Table 1 Physical and biotic characteristics of the sampling sites

\begin{tabular}{|c|c|c|c|c|c|}
\hline Station & Slope $\left(^{\circ}\right)$ & Maximum depth (m) & Prevailing winds & Depth level (m) & Pilot algal species \\
\hline 1 Kakia Skala & 90 & 65 & $\mathrm{~N}, \mathrm{NE}, \mathrm{SE}$ & $\begin{array}{l}15 \\
30 \\
40\end{array}$ & $\begin{array}{l}\text { Polysiphonia sp. } \\
\text { Polysiphonia sp., Lithophyllum sp. } \\
\text { Lithophyllum sp., Peyssonnelia sp. }\end{array}$ \\
\hline 2 Kelyfos & 70 & 35 & $\mathrm{~S}, \mathrm{SW}, \mathrm{SE}, \mathrm{NW}$ & $\begin{array}{l}15 \\
30\end{array}$ & $\begin{array}{l}\text { Padina pavonica, Polysiphonia sp. } \\
\text { Womersleyella setacea, Padina pavonica }\end{array}$ \\
\hline 3 Porto Koufo & 90 & 50 & SW & $\begin{array}{l}15 \\
30 \\
40\end{array}$ & $\begin{array}{l}\text { Womersleyella setacea } \\
\text { Womersleyella setacea } \\
\text { Lithophyllum } \mathrm{sp} ., \text { Peyssonnelia } \mathrm{sp} .\end{array}$ \\
\hline 4 Armenistis & $50-60$ & 35 & $\mathrm{NE}$ & $\begin{array}{l}15 \\
30\end{array}$ & $\begin{array}{l}\text { Womersleyella setacea, Padina pavonica } \\
\text { Womersleyella setacea }\end{array}$ \\
\hline 5 Vourvourou & 55 & 18 & $\mathrm{~N}, \mathrm{SE}$ & 15 & $\begin{array}{l}\text { Pseudolithophyllum expansum, Gelidium } \\
\text { pectinatum }\end{array}$ \\
\hline 6 Eleftheronissos & 70 & 30 & NE, SE, N, S & 30 & Lithothamnion sp., Polysiphonia sp. \\
\hline $7 \mathrm{~N}$. Iraklitsa & 65 & 35 & NE, NW, SE & $\begin{array}{l}15 \\
30\end{array}$ & $\begin{array}{l}\text { Cutleria multifida, Gelidium pectinatum } \\
\text { Cutleria multifida, Gelidium pectinatum }\end{array}$ \\
\hline
\end{tabular}

situation in the eastern Mediterranean (Nicolaidou et al. 1986; Bellan-Santini et al. 1994; Chintiroglou 1996; Ergen and Cinar 1997; Damianidis and Chintiroglou 2000).

According to Marinopoulos (1988), the infralittoral zone can be divided into three ecologically different belts. This study was restricted to the lowest belt (below $15 \mathrm{~m}$ ), where the sciaphilic alga community occurs (Laubier 1966; Margalef 1984; Antoniadou et al. 2004). Its aim was to reveal the spatial and temporal variability of the polychaete fauna associated with the sciaphilic alga community.

\section{Methods}

Sampling sites

Seven coastal stations were selected in the northern part of the Aegean Sea (Fig. 1). These sites share some common physical characteristics, such as hard substrate down to a depth of 30-40 m and an inclination of more than $50^{\circ}$ (for details see Antoniadou et al. 2004), which lead to the establishment of the sciaphilic alga community in the lower infralittoral zone $(15-40 \mathrm{~m})$. According to the vertical extension of the hard substrate, one to three depth levels $(15,30$ and $40 \mathrm{~m})$ were set at each station, covering the depth range of the local sciaphilic alga community. The main physical characteristics of the sampling sites are given in Table 1. For the spatial analysis, the sites were sampled during summer 1998 (stations 1-6) or summer 1999 (station 7). Station 3 was chosen for the temporal analysis (summer 1997 to summer 1998) due to its geomorphology 
protecting it from the N, NE and NW winds that usually occur in this area during winter.

Physico-chemical factors

Measurements of the main abiotic factors (temperature, salinity, conductivity, dissolved $\mathrm{O}_{2}$ and $\mathrm{pH}$ ) were carried out along the water column using a WTW salinity-conductivity- $\mathrm{O}_{2}$ meter and Lovibond Checkit ( $\mathrm{pH}$ meter) micro-electronic equipment. Water clarity was determined using a Secchi disc. The inclination of the hard substratum was calculated using a clinometer; currents (speed and direction) were recorded using the autographic current meter Sensordata SD-4 in May 2000

Data collection

Sampling was carried out by scuba diving using a quadrat sampler (Bellan-Santini 1969) covering a surface of $400 \mathrm{~cm}^{2}$ (Weinberg 1978; Karalis et al. 2003). Following Marinopoulos (1988), five replicates were collected at each depth level and site (see Table 1). A total of 75 and 65 samples were available for the study of spatial and seasonal variations, respectively. All samples were sieved $(0.5 \mathrm{~mm}$ mesh size $)$ and preserved in a $10 \%$ formalin solution. After sorting, all polychaetes were counted, weighted (wet weight) and identified to species level. Furthermore, the algae collected were identified, and the dominant species (in terms of percentage cover) were estimated.

\section{Statistics}

Common biocoenotic methods were employed to analyze the data (Hong 1982; Marinopoulos 1988; Antoniadou et al. 2004). Thus, the numerical abundance per square meter $\left(\mathrm{A} / \mathrm{m}^{2}\right)$, the mean dominance $(\mathrm{mD})$, the frequency $(\mathrm{F})$, and a variety of diversity indices (Margalef's richness, Shannon-Weaver $H^{\prime}$ and Pielou's evenness $J$ ' based on $\log _{2}$ ) were calculated.

In order to check the null hypothesis (no significant variations in polychaete abundance), a two-way mANOVA test was used to examine the effects of two different factors: depth, and space or time. A logarithmic transformation $(\log x+1)$ was used in order to normalize the variance of numerical abundance data in both cases (Zar 1984; Clarke and Green 1988).

The data obtained from each sampling site were analyzed using cluster and multidimensional scaling (MDS) techniques, based on the Bray-Curtis similarity and log-transformed numerical abundances, using the PRIMER package (Clarke and Warwick 1994). The significance of the multivariate results was assessed using the ANOSIM test. SIMPER analysis was applied in order to identify the percentage contribution of each species to the overall similarity within a site, and to the dissimilarity among sites (Clarke and Warwick 1994). Moreover, an abundance-biomass comparison (ABC curves) was performed for each site in order to detect any kind of disturbance in the examined assemblages (Warwick 1986). All the above techniques were employed in both the spatial and temporal analysis.

\section{Results}

Spatial variation

\section{Abiotic factors}

The main abiotic parameters showed slight variations in relation to depth and sampling site (Table 2). A detailed analysis is given by Antoniadou et al. (2004). Water currents follow the general pattern of cyclonic circulation in the northern Aegean Sea (Stergiou et al. 1997; Somarakis et al. 2002).

\section{Community description}

All sites can be classified to the sciaphilic alga community (Augier 1982; Pérès and Picard 1964; Bellan-Santini et al. 1994). However, according to the dominant algae, four facies could be distinguished:

1. A facies of the red alga Polysiphonia sp. or Womersleyella setacea;

2. A facies of the red alga Gelidium pectinatum and the brown alga Cutleria multifida;

3. A facies of the red algae Lithophyllum sp., Lithothamnion sp. and Peyssonnelia sp.; and

4. A facies with the mixed occurrence of the red algae Pseudolithophyllum expansum, Gelidium pectinatum, Lithophyllum sp. and Polysiphonia sp. (see Antoniadou et al. 2004).

The main biocoenotic parameters are presented in Table 3. Overall, 4,361 individuals were counted, belonging to 79 species. Twenty-four species were the most dominant: only Syllis hyalina and Nereis rava were present at all sites.
Table 2 Mean values of the main abiotic factors in the water column $(0-40 \mathrm{~m})$ for stations 1-7 (summer) and for seasons (station 3). $T$ temperature, $S$ salinity, $C$ conductivity, $W C$ water clarity, $C V$ water current velocity, $C D$ water current direction

\begin{tabular}{lllllllll}
\hline Station & $\mathrm{T}\left({ }^{\circ} \mathrm{C}\right)$ & $\mathrm{S}(\mathrm{psu})$ & $\mathrm{C}(\mu \mathrm{S} / \mathrm{cm})$ & $\mathrm{O}_{2}(\mathrm{mg} / \mathrm{l})$ & $\mathrm{pH}$ & $\mathrm{WC}(\mathrm{m})$ & $\mathrm{CV}(\mathrm{cm} / \mathrm{s})$ & $\mathrm{CD}$ \\
\hline 1 & 23.1 & 35.4 & 48.2 & 6.98 & 8.6 & 21 & 2.69 & $\mathrm{NE}$ \\
2 & 23.1 & 35.3 & 48.1 & 7.42 & 8.2 & 22 & 1.93 & $\mathrm{~N}$ \\
3 & 21.6 & 36.1 & 49.0 & 7.22 & 8.2 & 20 & 1.80 & $\mathrm{SW}$ \\
4 & 26.2 & 34.6 & 47.0 & 8.18 & 7.5 & 20 & 3.10 & $\mathrm{E}$ \\
5 & 25.9 & 34.9 & 47.3 & 7.64 & 8.2 & 12 & 2.74 & $\mathrm{SE}$ \\
6 & 23.1 & 34.8 & 47.5 & 7.73 & 8.1 & 21 & 11.40 & $\mathrm{~N}$ \\
7 & 25.7 & 33.2 & 45.5 & 7.75 & 8.7 & 18 & 1.58 & $\mathrm{NW}$ \\
Seasons & & & & & & & \\
Summer & 21.6 & 36.1 & 49.0 & 7.22 & 8.2 & 20 & & \\
Autumn & 19.3 & 36.8 & 50.2 & 6.72 & 8.2 & 23 & & \\
Winter & 12.9 & 37.4 & 51.3 & 6.84 & 8.2 & 18 & & \\
Spring & 14.1 & 36.9 & 50.8 & 8.25 & 8.2 & 16 & & \\
\hline
\end{tabular}


171

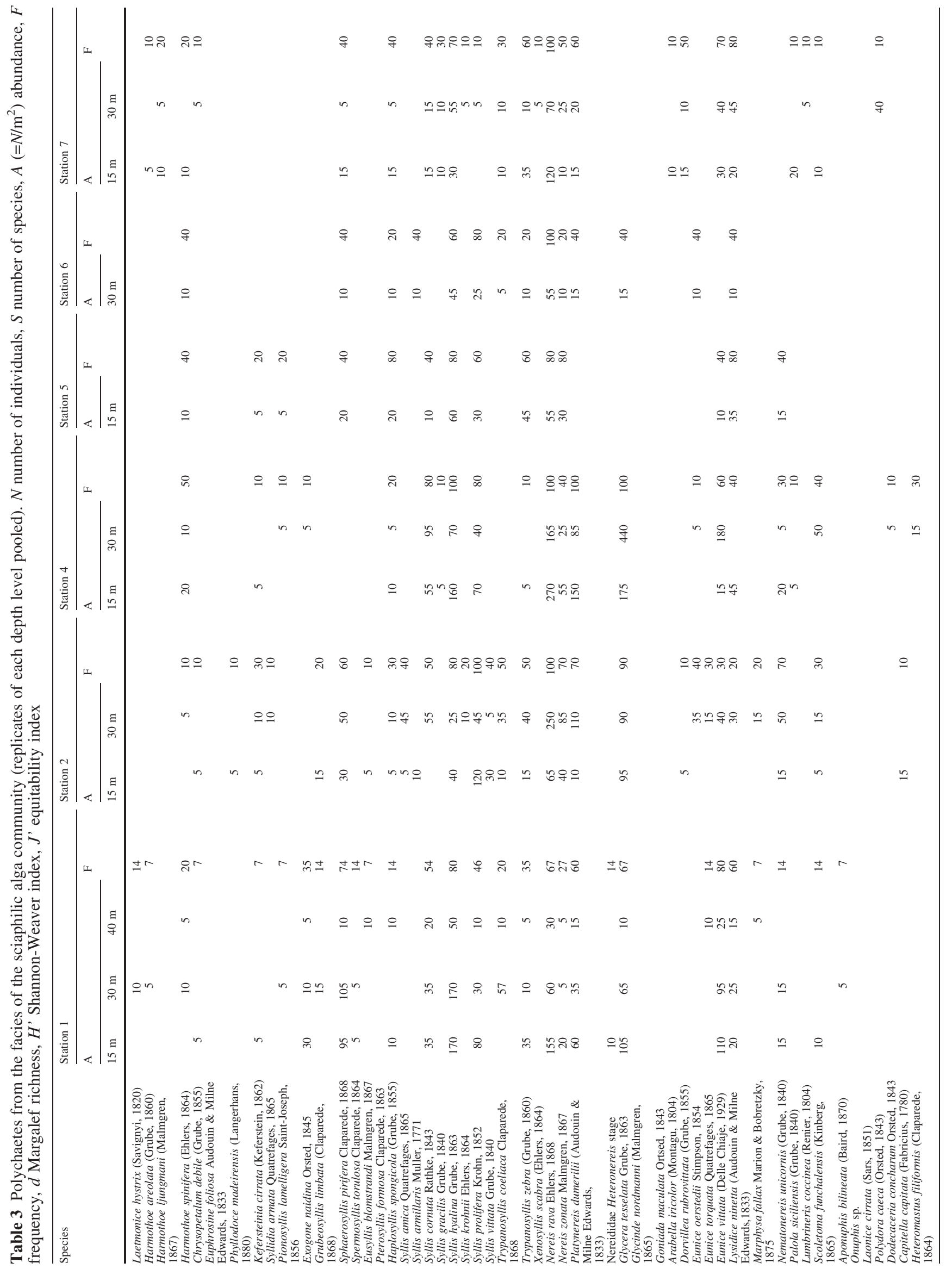




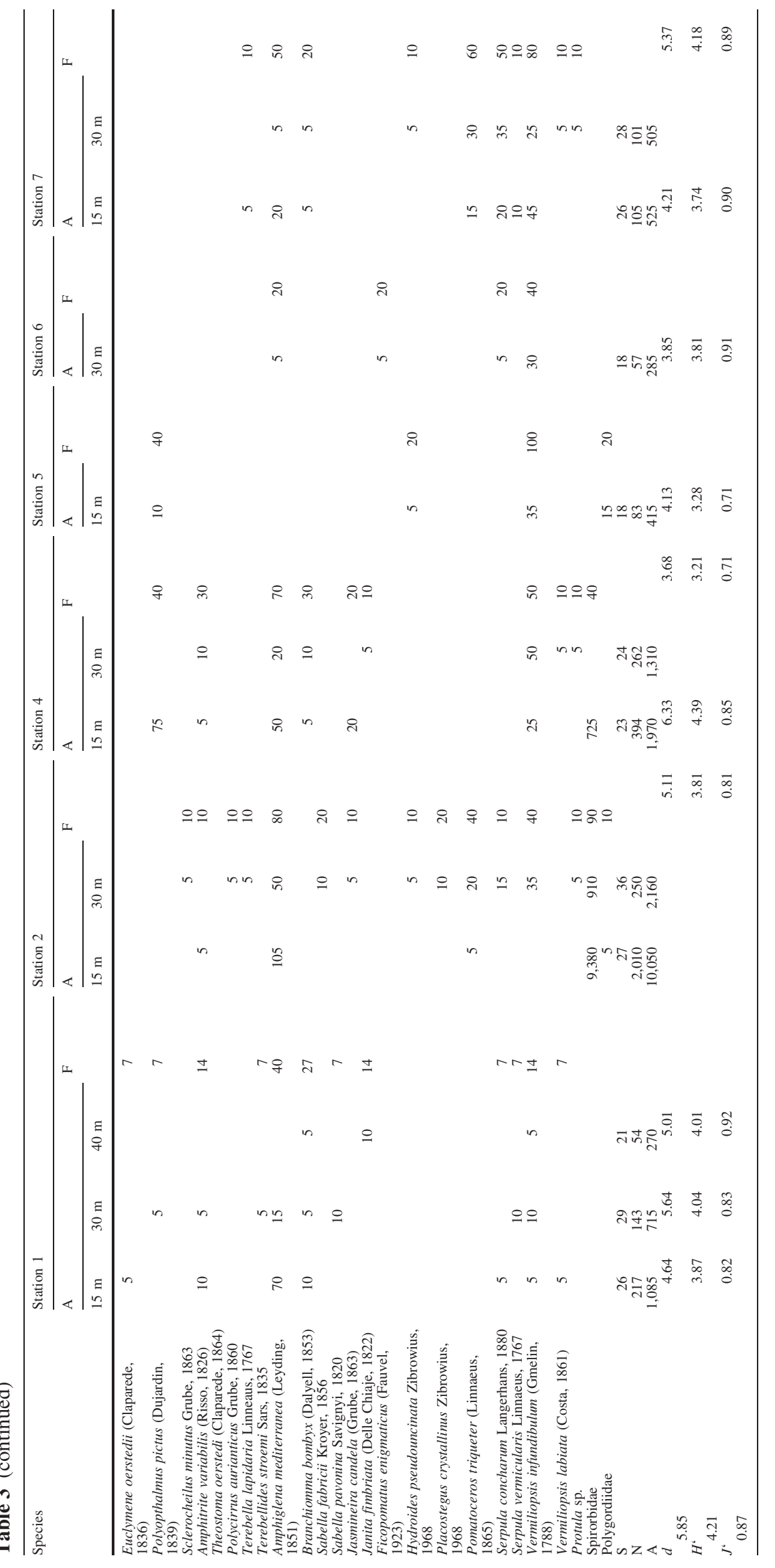




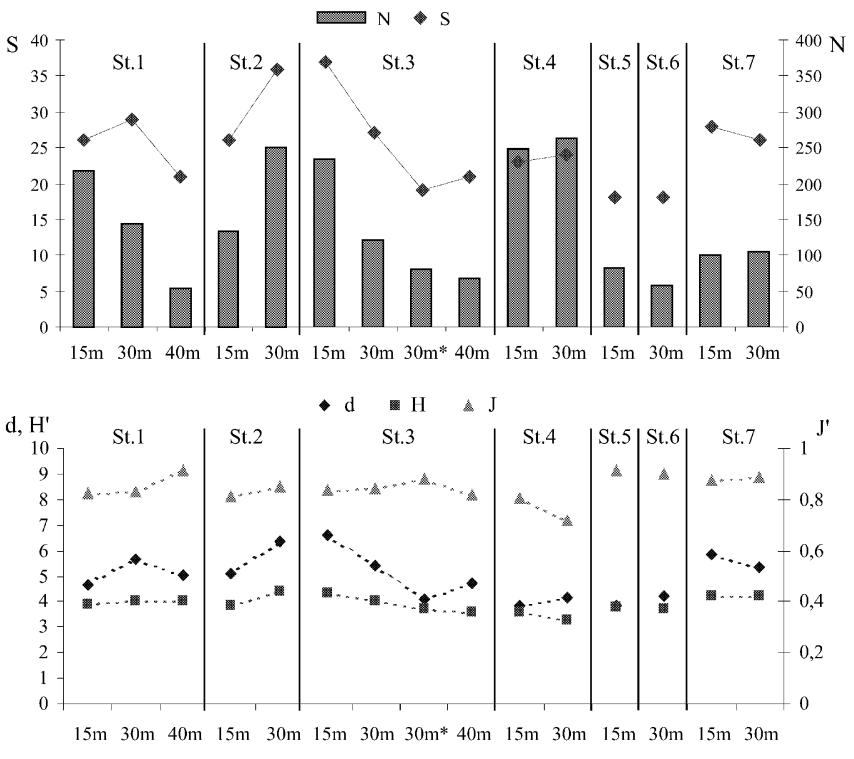

Fig. 2 Biocoenotic parameters (above) and diversity indices (below) for each depth level $(15,30,40 \mathrm{~m})$ and stations in summer. $d$ Margalef richness, $H$ ' Shannon-Weaver index, $J$ ' Pielou's evenness, $S$ number of species, $N$ number of individuals

\section{Abundance of polychaete fauna}

Concerning the spatial distribution, mANOVA showed that both depth and site had a significant effect $(F=15.94$, $P=0.001$ and $F=13.30 P=0.001$, respectively). The Fisher PLSD test indicated that differences exist between the three depth levels $(15,30$ and $40 \mathrm{~m})$ and between stations 2 and 4 on the one hand, and the rest of the stations on the other. Stations 2 and 4 are discriminated mainly due to the presence of high numbers of spirorbids. The decrease in polychaete abundance with depth is probably related to the algal vertical zonation: filamentous algae dominate in shallow waters, and encrusting algae in deep.

\section{Composition and diversity of polychaete fauna}

The spatial fluctuation of the diversity indices and of the total number of individuals $(N)$ and species $(S)$ at each depth level is shown in Fig. 2. Richness values $(D)$ ranged from 3.80 to $6.60, H^{\prime}$ values from 3.28 to 4.35 and $J$ ' values from 0.72 to 0.91 . These indices are a function of the number of species and individuals: high $N$ and low $S$ values result in low diversity indices. Spirorbids were excluded from the above calculation. They occurred at high numbers at stations $2(15$ and $30 \mathrm{~m})$ and $4(15 \mathrm{~m})$, reaching abundances of 9,380, 910 and 725 individuals/ $\mathrm{m}^{2}$, respectively, thus altering the diversity values.

\section{Affinity analysis}

The affinity of the samples (station, depth) is given in Fig. 3. Both analyses (cluster and non-metric MDS) in-

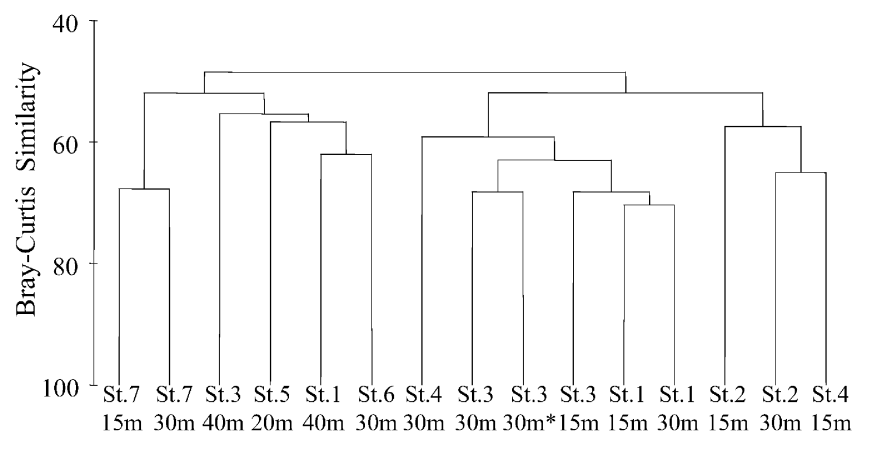

D

C

B

$\mathbf{A}$

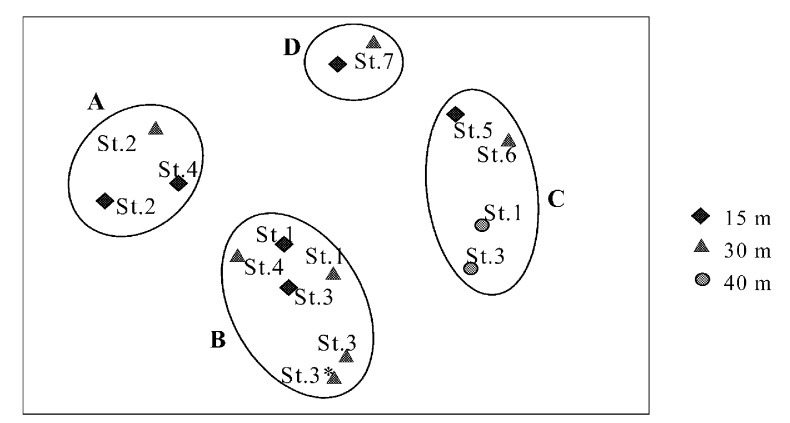

Fig. 3 Affinity of summer samples from different sites (stations 17) and depths $(15,30,40 \mathrm{~m}$ ). Results of cluster (above) and MDS (below) analysis based on Bray-Curtis similarity index

dicate a separation of the samples into four main groups at about 55\% similarity degree. The stress value for the twodimensional MDS configuration is 0.16 . The one-way ANOSIM test gave global $R=0.87$, at a significance level of $P<0.1$, indicating a good discrimination between the four basic groups. Further examination in order to localize the differences among the groups by means of a pairwise test did not reveal any significant variation in $R$ values, yet did show higher similarities between groups A and B, and between $\mathrm{C}$ and $\mathrm{D}$.

SIMPER analysis identified 6-9 (13-19) species as responsible for $60 \%(90 \%)$ of the average similarity of groups, and 16-20 (38-46) species as responsible for $60 \%$ (90\%) of the average dissimilarity of groups (Table 4).

The ABC curves (Fig. 4) show that, for most sites, the biomass curve was above that of abundance. Accordingly, the k-dominance pattern was produced. For station 2, however, the situation was reverse, and for station 4 the two curves coincide. This is due to the extremely high number of spirorbids, species with very small body size and thus negligible biomass.

\section{Temporal variation}

\section{Abiotic factors}

The seasonal pattern of the main abiotic parameters is summarized in Table 2. A seasonal thermocline was detected at about $20 \mathrm{~m}$ depth (end of July), while salinity and conductivity gained lower values during summer. 


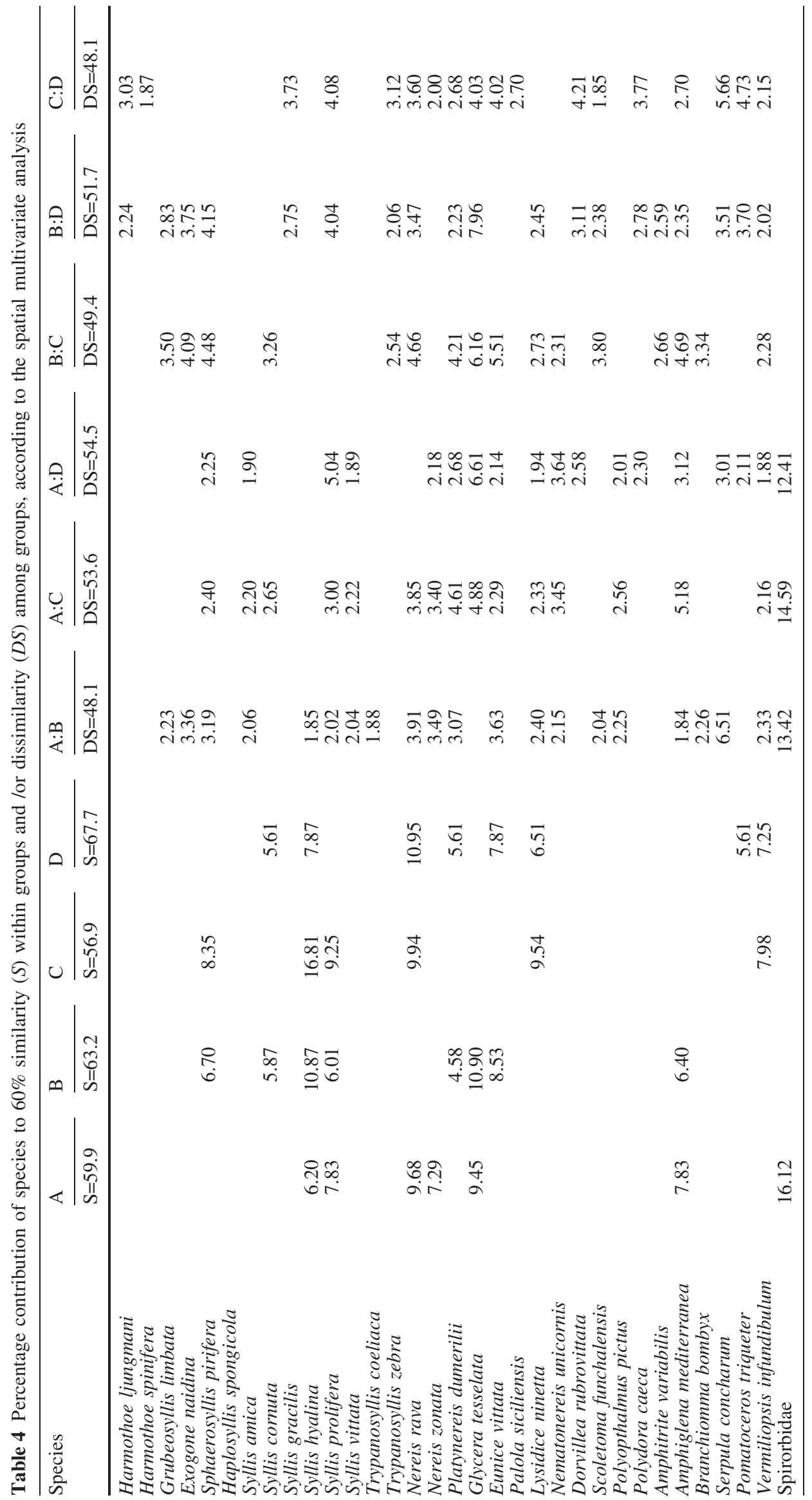


Fig. $4 \mathrm{ABC}$ curves for stations 1-7 (summer)
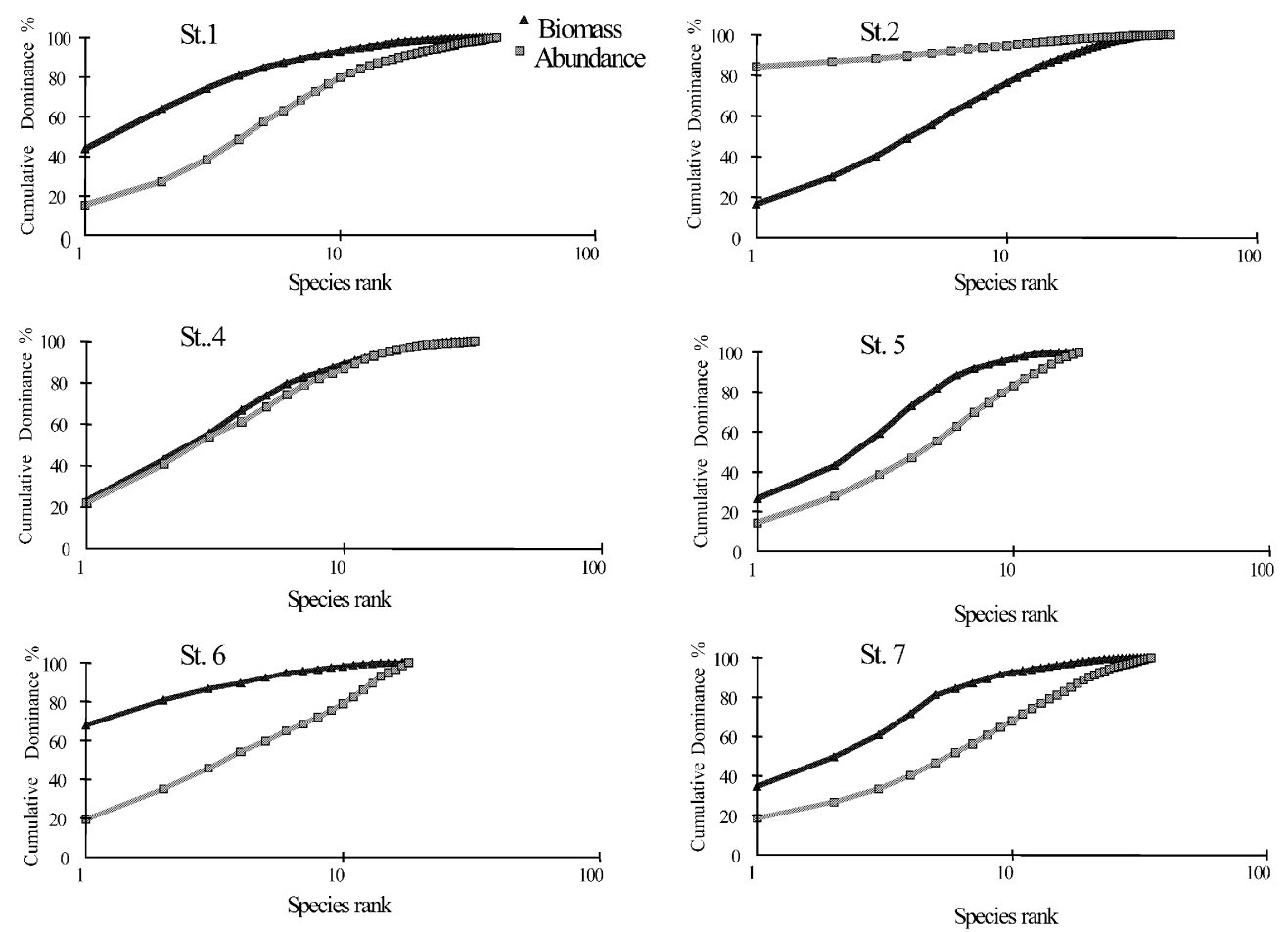

\section{Community description}

The main biocoenotic parameters are presented at Table 5. Overall 1,133 individuals were counted, belonging to 66 species. 24 species, largely the same as those reported in the spatial survey, were dominant in the seasonal samples. Syllis hyalina, Sphaerosyllis pirifera, Glycera tesselata and Vermiliopsis infundibulum were dominant in all seasons.

\section{Abundance of polychaete fauna}

Only depth had a significant effect (mANOVA: $F=6.58$, $P=0.002)$. The Fisher PLSD procedure revealed that this effect was restricted to $40 \mathrm{~m}$ versus 15 and $30 \mathrm{~m}$. No direct seasonal effect on polychaete abundance was detectable $(F=2.30, P=0.06)$.

\section{Composition and diversity of polychaete fauna}

The temporal fluctuation of the diversity indices, the total number of individuals $(N)$ and the number of species $(S)$ at each depth level is shown in Fig. 5. Richness values $(D)$ ranged from 3.91 to $6.48, H^{\prime}$ values from 3.45 to 4.41 , and evenness values $\left(J^{\prime}\right)$ from 0.80 to 0.97 . In general, diversity indices varied among seasons.
Affinity analysis

The seasonal discrimination of samples is given in Fig. 6 . Five groups (A-E) can be distinguished at about $50 \%$ similarity level. The stress value for the two-dimensional configuration is 0.12 , indicating a good ordination (Clarke and Warwick 1994). The ANOSIM test confirms the results of the discriminative techniques $(R=0.88, P<0.1)$. The pairwise test showed that the variations were significant in all cases ( $R$ ranging from 0.75 to 1 ).

SIMPER analysis identified 5-7 (10-17) species as responsible for $60 \%(90 \%)$ of the average similarity of groups, and 12-20 (22-38) species as responsible for $60 \%$ $(90 \%)$ of the average dissimilarity of groups (Table 6).

The ABC curves for different seasons show biomass curves being always above those of abundance (Fig. 7). Therefore, the k-strategy pattern dominated throughout the year.

\section{Discussion}

According to Pérès and Picard (1964), the Mediterranean infralittoral zone comprises two distinct communities: the photophilic alga community (at the upper level) and the sciaphilic alga community (at the lower level, often mentioned as precoralligenous and coralligenous). These two communities share some common characteristics: they both depend on the presence of different algal forms (Bellan-Santini et al. 1994) and are influenced by the hydrodynamism and light (Hong 1982; Marinopoulos 1988). 
176

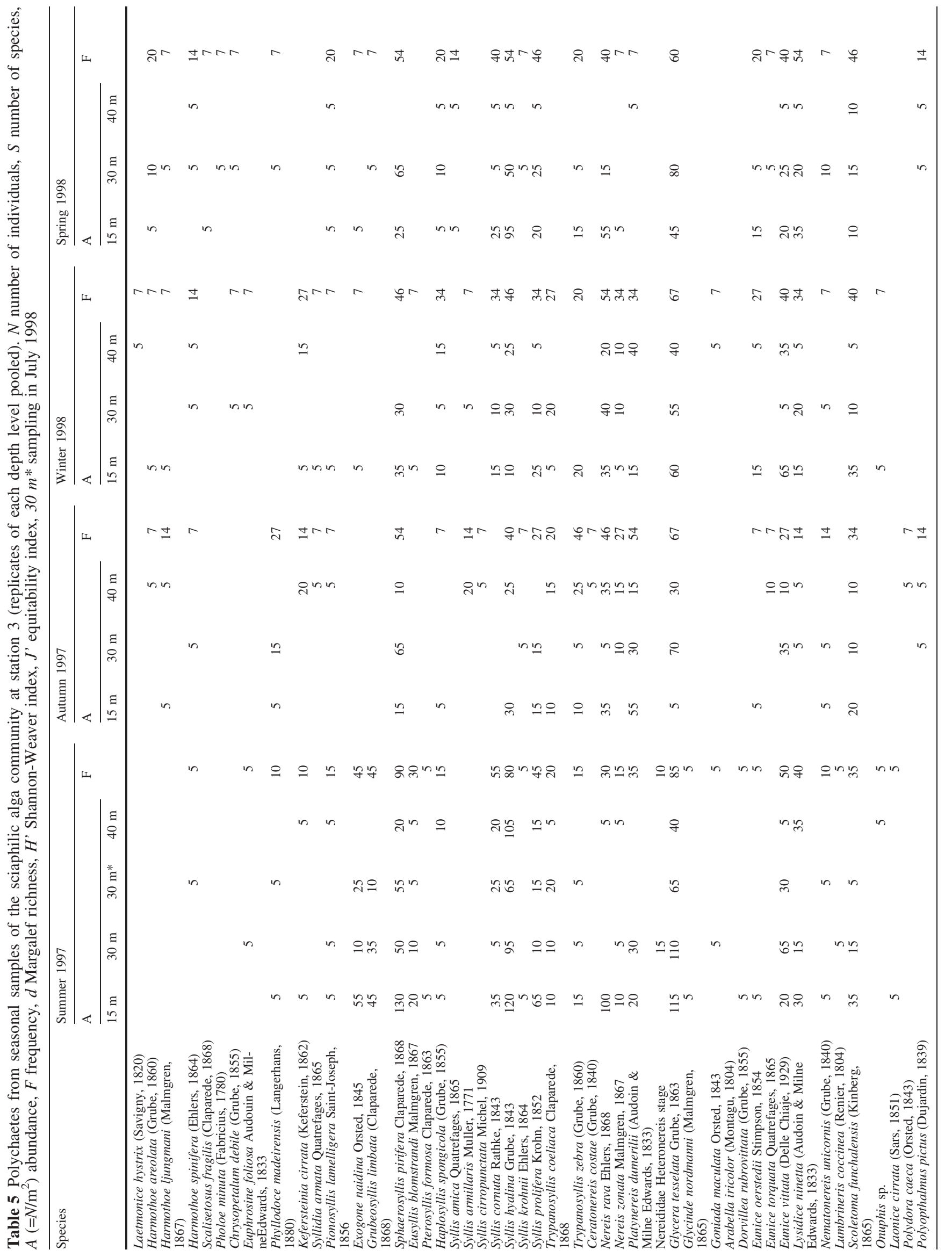




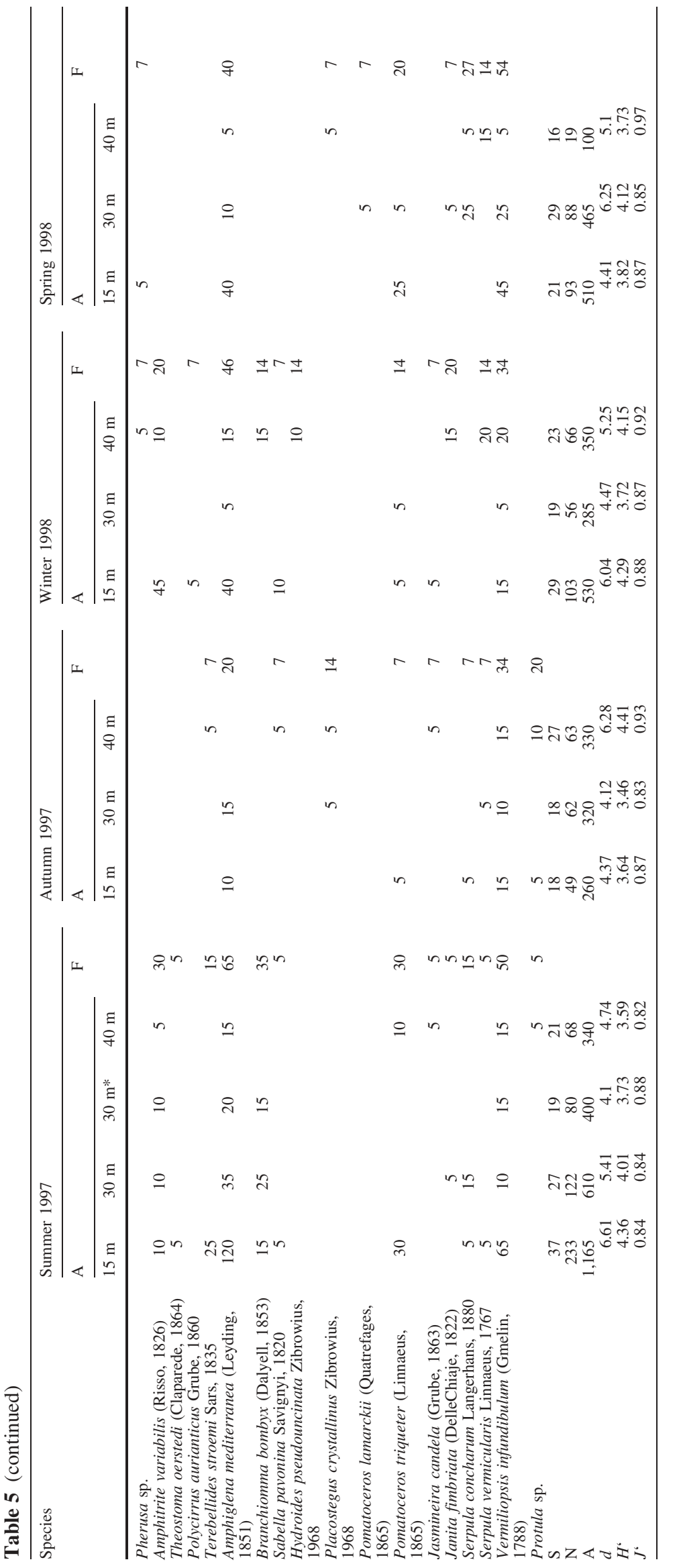




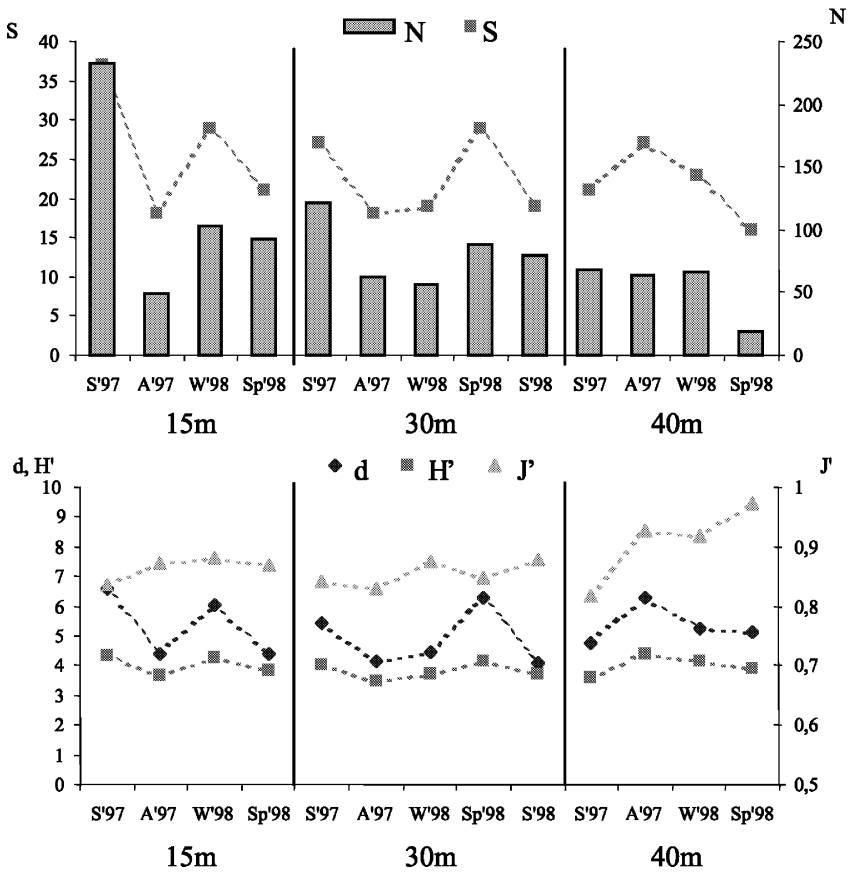

Fig. 5 Biocoenotic parameters (above) and diversity indices (below) over an annual cycle at station $3(15,30,40 \mathrm{~m}$ depth). $S$ summer, $A$ autumn, $W$ winter, $S p$ spring, $d$ Margalef richness, $H^{\prime}$ Shannon-Weaver index, $J$ ' Pielou's evenness, $S$ number of species, $N$ number of individuals

Bellan (1964, 1969) studied the photophilic alga community and found 128 species of Polychaeta which were classified, according to their ecological preferences, to 11 discrete "stocks". Cardell and Gili (1988) studied the facies of Lithophyllum tortuosum and recorded 71 species. They concluded that this assemblage is very homogeneous, both spatially and temporally. However, Sphaerosyllis pirifera and Platynereis dumerilii showed an increase in numerical abundance in summer. Most species were common in the hard substrate stock (Bellan 1969), and especially within the photophilic alga community: some species were characteristic of the concretioned substrate (Laubier 1966; Sardà 1991). Fraschetti et al. (2002) studied the facies of Cystoseira amentacea and found 59 species of Polychaeta, most of which were common species among sublittoral photophilic algae (Sardà 1991). The same authors did not find any noticeable seasonal changes, with the exception of the large numbers of Platynereis dumerilii in summer. Chintiroglou (1996) reported 87 species associated with Cladocora caespitosa colonies at 5-18 m depth, and Damianidis and Chintiroglou (2000) recognized 48 species associated with Mytilus galloprovincialis assemblages in the upper infralittoral zone. Sardà (1991), in a study of hard substrate communities from 1 to $40 \mathrm{~m}$ depth, found 220 species and discriminated five distinct communities: the Lithophyllum lichenoides (with the lowest diversity), the shallow photophilic, the deeper photophilic, the Posidonia oceanica rhizomes and the infralittoral sciaphilous community. The contributions of the different ecological

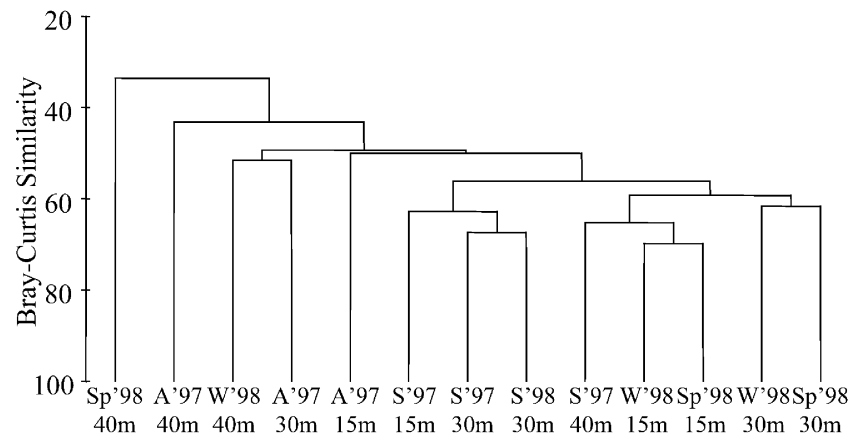

$\begin{array}{lllll}\text { A } & \text { B } & \text { C } & \text { D } & \text { E }\end{array}$

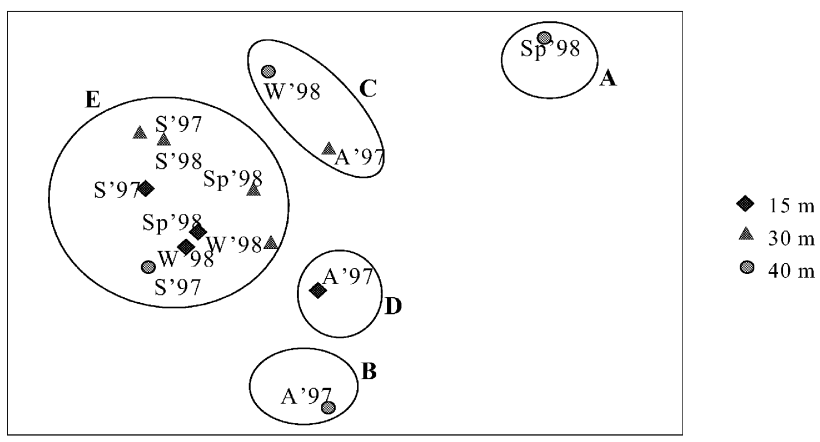

Fig. 6 Affinity of seasonal samples from different depths at station 3. Results of cluster (above) and MDS (below) analysis based on Bray-Curtis similarity index

stocks (Bellan 1969) to these communities change according to habitat complexity. In our study, we found 79 species of polychaetes in the sciaphilic alga community (15-40 m), while Marinopoulos (1988) found 36 (21 common) at similar depths. Most of these species are members of the photophilic alga community, but there is also a significant contribution of cryptic, hard substrate, soft substrate and coralligenous (concretioned substrate) species. It seems that polychaetes have a large ecological tolerance and that their occurrence is largely dependent on substrate availability and complexity (Bellan 1964, 1969; Hong 1982). We found clear spatial differences in polychaete distribution, while temporal differences were less apparent. The spatial distribution of polychaetes largely corresponds with the occurrence of different algal facies. We have noted a high affinity between stations 1 and 3 at all depth levels. This could be expected, since these two sites share some common characteristics such as the high inclination $\left(\sim 90^{\circ}\right)$ and large bathymetrical extension of the rocky substrate. Station 7 is separated, probably due to abiotic parameters (low salinity). Its relatively moderate inclination sets station 7 near to stations 5 and 6 , while the sharpest slope ranks stations 2 and 4 closer to stations 1 and 3 . The depth level of $40 \mathrm{~m}$ (stations 1 and 3 ) shows high affinity with stations 5 and 6 , as it hosts a fairly low number of polychaete species and individuals. SIMPER analysis showed that both the similarities within groups and the dissimilarities between groups were the result of small contributions of a large number of species, indicating a diverse community with a 
Fig. 7 ABC curves for different seasons (station 3 ). $S$ summer, $A$ autumn, $W$ winter, $S p$ spring
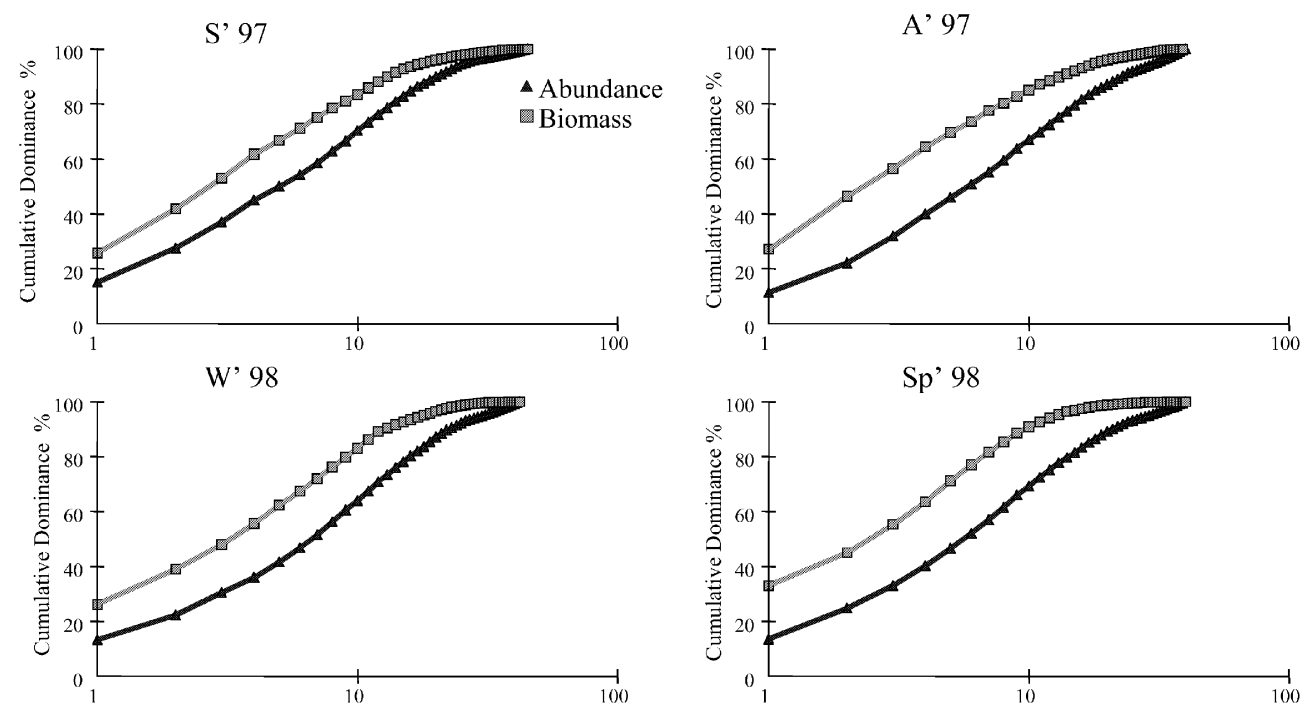

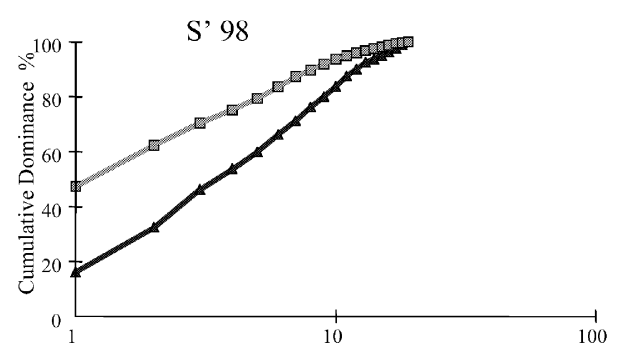

highly complex structure (Dahl and Dahl 2002). This heterogeneity may result from the presence of several algal species of different architecture (Chemello and Milazzo 2002). Fan-shaped structures and filamentous forms dominate group A, filamentous forms group B, encrusting forms group $\mathrm{C}$, and filamentous bush-like encrusting forms group D. Many authors have stated that polychaetes are not related to specific algal species, but to specific algal architectures (Naim and Amoureux 1982; Sardà 1988; Gambi et al. 1995; Fraschetti et al. 2002). Groups A and B are characterized by high diversity and abundance in comparison to groups $\mathrm{C}$ and $\mathrm{D}$. It should be noted that the high abundance in group $\mathrm{A}$ is mainly due to the presence of high numbers of spirorbids attached to the thalli of Padina pavonica. Spirorbids are capable of settling immediately after release from parental tubes and are typically multiannual in the sense of Fauchald (1983), living in unstable environments. They probably perish when the thalli of Padina pavonica decay after midSeptember (Diapoulis and Koussouris 1988). Spirorbids strongly influence the discrimination of group A, the $\mathrm{ABC}$ analysis and the diversity indices. Another difference was found in the polychaete fauna associated with the two filamentous Rhodomelacea, Womersleyella setacea and Polysiphonia sp. An abundant and diversified polychaete is associated only with the former. Womersleyella setacea is an introduced and probably invasive species (Boudouresque and Verlaque 2002) which has spread over the Mediterranean (Verlaque 1989; Airoldi et al. 1995) and the northern Aegean Sea (Athanassiadis
1997). It forms paucispecific populations with increasing turf development. These turfs trap sediment, forming a stratum that prevents the development of other algal species on the rocky substrate (Piazzi and Cinelli 2000). However, the entrapped sediment increases the complexity of the system, offering suitable microhabitats for the settlement of many soft-sediment polychaete species.

The study of temporal changes in polychaete distribution revealed that summer is distinct from the other three seasons. Winter and spring form an even group, while autumn branches out according to depth. This is the case for the upper depth levels (15 and $30 \mathrm{~m})$, where Womersleyella setacea dominated throughout the year. This species is capable of continuous vegetative reproduction (Athanassiadis 1997), creating a very stable and homogenous habitat which may contribute to the lack of seasonality. The image is much more complicated at the 40-mdepth level, where the dominant algae were represented by various species of Corallinacea and Peyssonneliacea. Here, summer samples were similar to winter ones, while autumn and spring samples discriminated.

According to the relevant literature, there is no distinct seasonality in the lower infralittoral zone, in contrast to the upper one (Hong 1982; Marinopoulos 1988). However, a discrimination of summer is frequently observed (Damianidis and Chintiroglou 2000) and may be due mainly to the massive recruitment of a few species, e.g. Platynereis dumerilii (Cardell and Gili 1988; Fraschetti et al. 2002). In our study, the bathymetric distribution of polychaetes changed with season, while the species in- 


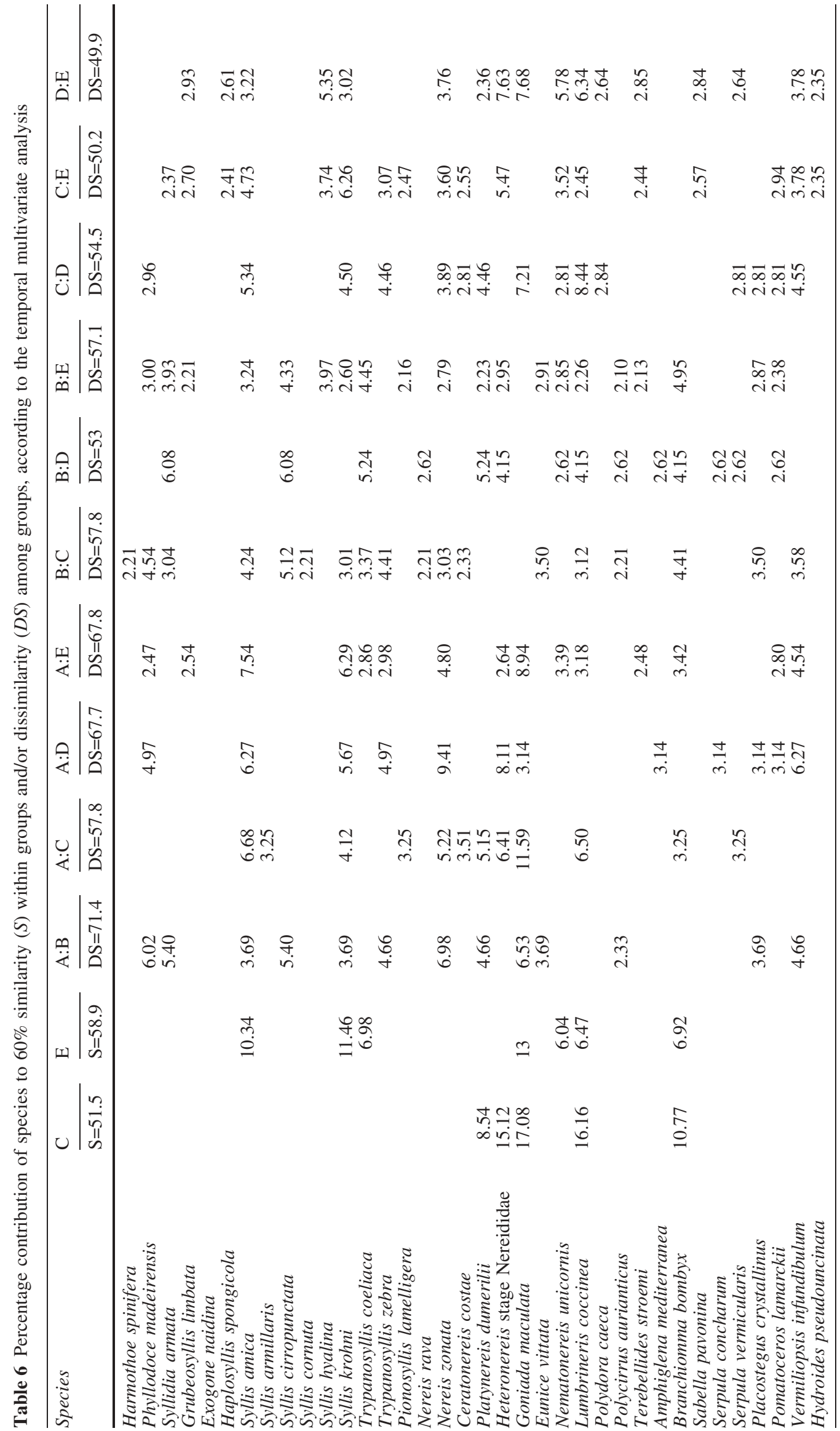


ventory at the stations remained unchanged throughout the year. Marinopoulos (1988) also found seasonal changes in the abundance of polychaetes at different depths, with the same species (Syllis hyalina, Syllis prolifera, Syllis vittata, Platynereis dumerilii and Sphaerosyllis pirifera) being abundant at low depth during summer and in deeper waters during winter. It seems that the seasonality of the sciaphilic alga community is mainly achieved by a vertical rearrangement of the abundances of different polychaete species.

\section{References}

Abbiati M, Bianchi CN, Castelli A (1987) Polychaete vertical zonation along a littoral cliff in the west Mediterranean. PSZNI Mar Ecol 8:33-48

Airoldi L, Rindi F, Piazzi L, Cinelli F (1995) Distribuzione di Polysiphonia setacea (Rhodomelacea, Rhodophyta) Hollenberg in Mediterraneo e possibili modalita di diffusione. Biol Mar Médit 2:343-344

Antoniadou C, Koutsoubas D, Chintiroglou C (2004) Molluscan fauna from infralittoral hard substrate assemblages in the North Aegean Sea. Belg J Zool (in press)

Athanassiadis A (1997) North Aegean marine algae IV. Womersleyella setacea (Hollenberg) R.E. Norris (Rhodophyta, Ceramiales). Bot Mar 40:473-476

Augier H (1982) Inventory and classification of marine benthic biocenoses of the Mediterranean. Council of Europe, Strasbourg, Publication Section

Bellan G (1964) Contribution à l'étude systématique bionomique et écologique des Annélides Polychètes de la Méditerranée. Thesis, Université Aix-Marseille, France

Bellan G (1969) Polychètes des horizons supérieurs de l'étage infralittoral rocheux dans la région Provençale. Téthys 1:349-366

Bellan G (1980) Relationship of pollution to rocky substratum polychaetes on the French Mediterranean coast. Mar Pollut Bull 11:318-321

Bellan-Santini D (1969) Contribution a l'étude des peuplements infralittoraux sur substrat rocheux. Thesis, Université AixMarseille, France

Bellan-Santini D, Lacazet JC, Poizat C (1994) Les biocénoses marines et littorales de Méditerranée, synthèse, menaces et perspectives. Muséum National d'Histoire Naturelle, Paris

Bianchi CN, Morri C (2000) Marine biodiversity of the Mediterranean Sea: situation, problems and prospects for future research. Mar Pollut Bull 40:367-376

Boudouresque CF, Verlaque M (2002) Biological pollution in the Mediterranean Sea: invasive versus introduced macrophytes. Mar Pollut Bull 44:32-38

Cardell MJ, Gili JM (1988) Distribution of a population of annelid polychaetes in the "trottoir" of the midlittoral zone on the coast of North-East Spain, Western Mediterranean. Mar Biol 99:8392

CBDMS (1995) Understanding marine biodiversity. A research agenda for the nation. National Academy Press, Washington, USA

Chemello R, Milazzo M (2002) Effect of algal architecture on associated fauna: some evidence from phytal mollusks. Mar Biol 140:981-990

Chintiroglou C (1996) Feeding guilds of polychaetes associated with Cladocora caespitosa (L.) (Anthozoa, Cnidaria) in the North Aegean Sea. Isr J Zool 42:261-274

Clarke KR, Green RH (1988) Statistical design and analysis for a 'biological effects' study. Mar Ecol Prog Ser 46:213-226

Clarke KR, Warwick RM (1994) Change in marine communities: an approach to statistical analysis and interpretation. Natural Environment Research Council, UK
Costello MJ (1998) To know, research, manage and conserve marine biodiversity. Océanis 24:25-49

Costello MJ, Emblow CS, Picton BE (1996) Long term trends in the discovery of marine species new to science, which occur in Britain and Ireland. J Mar Biolog Assoc UK 76:255-257

Dahl L, Dahl K (2002) Temporal, spatial and substrate-dependent variations of Danish hard-bottom macrofauna. Helgol Mar Res 56:159-168

Damianidis P, Chintiroglou C (2000) Structure and function of Polychaetofauna living in Mytilus galloprovincialis assemblages in Thermaikos Gulf (N. Aegean Sea). Oceanol Acta 23:323-337

Diapoulis A, Koussouris T (1988) Biogeographical affinities of marine algae in the Saronikos gulf, Athens, Greece. Geogr J $17: 85-89$

Ergen Z, Cinar ME (1997) Polychaeta of the Antalya bay (Mediterranean coast of Turkey). Isr J Zool 43:229-241

Fauchald K (1983) Life diagram patterns in benthic polychaetes. Proc Biol Soc Wash 96:160-177

Fauchald K, Jumars P (1979) The diet of worms: a study of Polychaete feeding guilds. Oceanogr Mar Biol Annu Rev 17:193-284

Fraschetti S, Giangrande A, Terlizzi A, Miglietta MP, Della Tommasa L, Boero F (2002) Spatio-temporal variation of hydroids and polychaetes associated with Cystoseira amentacea (Fucales: Phaeophyceae). Mar Biol 140:949-957

Gambi MC, Giangrande A, Martinelli M, Chessa LA (1995) Polychaetes of a Posidonia oceanica bed off Sardinia (Italy): Spatio-temporal distribution and feeding guilds analysis. Sci Mar 59:129-141

Gaston K, Spicer JI (1996) Biodiversity. An introduction. Blackwell, Oxford, UK

Giangrande A (1988) Polychaete zonation and its relation to algal distribution down a vertical cliff in the Western Mediterranean (Italy): a structural analysis. J Exp Mar Biol Ecol 120:263-276

Hong JS (1982) Contribution a l'étude des peuplements d'un fond de Concrétionnent Coralligène dans la région marseillaise en Méditerranée Nord-Occidental. Bull Kor 4:27-51

Karalis P, Antoniadou C, Chintiroglou C (2003) Structure of the artificial hard substrate assemblages in ports in Thermaikos Gulf (North Aegean Sea). Oceanol Acta 26:215-224

Laubier L (1966) Le Coralligène des Albères. Monographie biocénotique. Adaptations chez les Annélides Polychètes interstitielles. Thesis, Masson, Paris, France

Margalef R (1984) Introduction to the Mediterranean. In: Margalef R (eds) Western Mediterranean. Pergamon Press, Oxford, UK, pp 11-16

Marinopoulos J (1988) Etude des peuplements infralittoraux de substrats rocheux de la région de Marseille et des facteurs abiotiques (lumière, hydrodynamique) les influençant. Thesis, Université Aix-Marseille, France

Naim O, Amoureux L (1982) Le peuplement d'annélides polychètes mobiles associé aux algues d'un récif coralline de Polynésie Française (Ile de Moorea, Archipel de la Société). Bull Ecol 13:25-33

Nicolaidou A, Papadopoulou NK, Simboura N (1986) Taxonomic and ecological study of the polychaete fauna of the N. Sporades, Aegean Sea. Rapp Comm Int Mer Médit 30:20

Pérès JM, Picard J (1964) Nouveau manuel de la bionomie benthique de la mer Méditerranée. Rec Trav Stat Mar Endoume 31: $1-137$

Piazzi L, Cinelli F (2000) Effets de l'expansion des Rhodophycée introduites Acrothamnion preissi et Womersleyella setacea sur les communautés algales des rhizomes de Posidonia oceanica de Méditerranée occidentale. Cryptogam Algol 21:291-300

Pocklington P, Wells PG (1992) Polychaetes: key taxa for marine environmental quality monitoring. Mar Pollut Bull 24:593-598

Reish DJ (1978) The effects of heavy metals on Polychaetous Annelids. Rev Int Oceanogr Médit 19:99-104

Retiere C, Richoux P (1973) Ecologie des Polychaetes des lithoclases intertidales. Cah Biol Mar 14:39-55 
Sardà R (1987) Asociaciones de Anelidos Poliquetos sobre sustrato duro en la region del estrecho de Gibraltar ( $\mathrm{S}$ de Espana). Inv Pesq 51:243-262

Sardà R (1988) Fauna de Anelidos Poliquetos de la region del estrecho de Gibraltar II. Datos cualitativos poblacionales de las diferentes facies algales. Bull Inst Cat Hist Nat 55:5-15

Sardà R (1991) Polychaete communities related to plant covering in the midlittoral and infralittoral zones of the Balearic Islands (Western Mediterranean). PSZNI Mar Ecol 12:341-360

Somarakis S, Drakopoulos P, Filippou V (2002) Distribution and abundance of larval fish in the Northern Aegean Sea, Eastern Mediterranean, in relation to early summer oceanographic conditions. J Plankton Res 24:339-357

Somaschini A (1988) Policheti della biocenosi ad alghe fotofile (Facies a Corallina elongata) nel Lazio settentrionale. Atti Sac. Toscana Sci Nat Mem Ser B 95:83-94

Stergiou KI, Christou ED, Georgopoulos D, Zenetos A, Souvermezoglou C (1997) The Hellenic Seas: physics, chemistry, biology and fisheries. Oceanogr Mar Biol Annu Rev 35:415538

Verlaque M (1989) Contribution a la flore des algues marines Méditerranée: Espèces rares ou nouvelles pour les cotes Françaises. Bot Mar 32:101-113

Warwick M (1986) A new method for detecting pollution effects on marine macrobenthic communities. Mar Biol 92:557-562

Warwick M (1993) Environmental impact studies on marine communities: pragmatical considerations. Aust J Ecol 18:63-80

Weinberg S (1978) The minimal area problem in invertebrate communities of Mediterranean rocky substrate. Mar Biol 49:33-40

Wenner AM (1988) Crustaceans and other invertebrates as indicators of beach pollution. In: Soule DF, Kleppel GS (eds) Marine organisms as indicators. Springer, Berlin Heidelberg New York, pp 199-299

Zar JH (1984) Biostatistical analysis. Prentice Hall, New Jersey, USA 